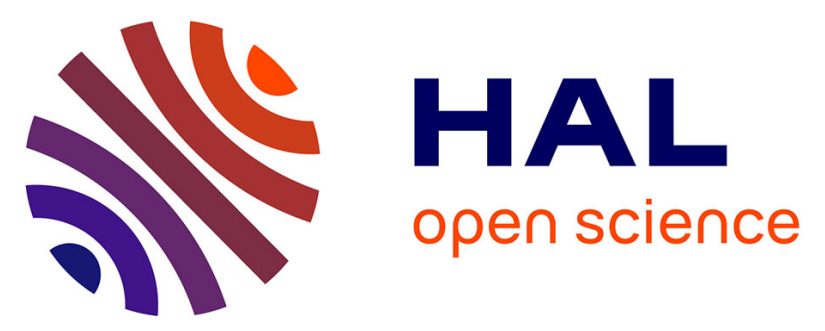

\title{
Characterisation of the CTX-M-15-encoding gene in Klebsiella pneumoniae strains from the Barcelona metropolitan area: plasmid diversity and chromosomal integration
}

\author{
Alicia Coelho, Juan José González-López, Elisenda Miró, Carles \\ Alonso-Tarrés, Beatriz Mirelis, María Nieves Larrosa, Rosa María Bartolomé, \\ Antonia Andreu, Ferran Navarro, James R. Johnson, et al.
}

\section{- To cite this version:}

Alicia Coelho, Juan José González-López, Elisenda Miró, Carles Alonso-Tarrés, Beatriz Mirelis, et al.. Characterisation of the CTX-M-15-encoding gene in Klebsiella pneumoniae strains from the Barcelona metropolitan area: plasmid diversity and chromosomal integration. International Journal of Antimicrobial Agents, 2010, 36 (1), pp.73. 10.1016/j.ijantimicag.2010.03.005 . hal-00594504

\author{
HAL Id: hal-00594504 \\ https://hal.science/hal-00594504
}

Submitted on 20 May 2011

HAL is a multi-disciplinary open access archive for the deposit and dissemination of scientific research documents, whether they are published or not. The documents may come from teaching and research institutions in France or abroad, or from public or private research centers.
L'archive ouverte pluridisciplinaire HAL, est destinée au dépôt et à la diffusion de documents scientifiques de niveau recherche, publiés ou non, émanant des établissements d'enseignement et de recherche français ou étrangers, des laboratoires publics ou privés. 


\section{Accepted Manuscript}

Title: Characterisation of the CTX-M-15-encoding gene in Klebsiella pneumoniae strains from the Barcelona metropolitan area: plasmid diversity and chromosomal integration

Authors: Alicia Coelho, Juan José González-López, Elisenda

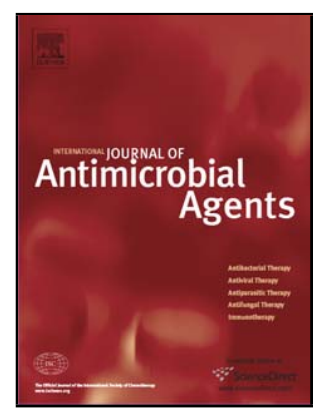

Miró, Carles Alonso-Tarrés, Beatriz Mirelis, María Nieves

Larrosa, Rosa María Bartolomé, Antonia Andreu, Ferran

Navarro, James R. Johnson, Guillem Prats

PII:

S0924-8579(10)00120-2

DOI: doi:10.1016/j.ijantimicag.2010.03.005

Reference:

ANTAGE 3278

To appear in:

International

Journal

of

Antimicrobial

Agents

Received date: $\quad 20-1-2010$

Accepted date: $\quad 3-3-2010$

Please cite this article as: Coelho A, González-López JJ, Miró E, Alonso-Tarrés C, Mirelis B, Larrosa MN, Bartolomé RM, Andreu A, Navarro F, Johnson JR, Prats G, Characterisation of the CTX-M-15-encoding gene in Klebsiella pneumoniae strains from the Barcelona metropolitan area: plasmid diversity and chromosomal integration, International Journal of Antimicrobial Agents (2008), doi:10.1016/j.ijantimicag.2010.03.005

This is a PDF file of an unedited manuscript that has been accepted for publication. As a service to our customers we are providing this early version of the manuscript. The manuscript will undergo copyediting, typesetting, and review of the resulting proof before it is published in its final form. Please note that during the production process errors may be discovered which could affect the content, and all legal disclaimers that apply to the journal pertain. 


\section{Characterisation of the CTX-M-15-encoding gene in Klebsiella pneumoniae strains from the Barcelona metropolitan area: plasmid diversity and chromosomal integration}

Alicia Coelho ${ }^{a, b}$, Juan José González-López ${ }^{a, b}$, Elisenda Miró ${ }^{c}$, Carles Alonso-Tarrés ${ }^{d}$, Beatriz Mirelis $^{\mathrm{b}, \mathrm{c}}$, María Nieves Larrosa ${ }^{\mathrm{a}, \mathrm{b}}$, Rosa María Bartolomé ${ }^{\mathrm{a}, \mathrm{b}}$, Antonia Andreu ${ }^{\mathrm{a}, \mathrm{b}}$, Ferran Navarro ${ }^{b, c}$, James R. Johnson ${ }^{e}$, Guillem Prats ${ }^{a, b, *}$

a Servicio de Microbiología, Hospital Vall d'Hebron, 08035 Barcelona, Spain

${ }^{b}$ Universitat Autònoma de Barcelona, Barcelona, Spain

' Servicio de Microbiología, Hospital de la Santa Creu i Sant Pau, Barcelona, Spain

d Servicio de Microbiología, Hospital General de l'Hospitalet, Barcelona, Spain

e Veterans Affairs Medical Center and University of Minnesota, Minneapolis, MN, USA

ARTICLE INFO

Article history:

Received 20 January 2010

Accepted 3 March 2010

Keywords:

bla

Replicon

Klebsiella pneumoniae

* Corresponding author. Tel.: +34 9327468 67; fax: + 34932746801. 
E-mail address: gprats@vhebron.net (G. Prats). 


\section{ABSTRACT}

The localisation and genetic organisation of bla CTX-M-15 were studied in 37 CTX-M-15producing Klebsiella pneumoniae isolates collected from 2005 to 2008 within the Barcelona metropolitan area. Polymerase chain reaction (PCR)-based replicon typing and Southern hybridisations were used to identify the blacTX-M-15 location. The genetic environment was analysed by PCR mapping and sequencing, and transferability of blactXM-15 was evaluated by conjugation and transformation assays. The majority of the 37 isolates carried blacTX-M-15 in a plasmid location, frequently associated with the aac(6')-Ib-cr gene. Plasmids encoding bla IncFIlk, the latter two not having been described previously in association with blacTX-M-15. Several of these plasmids were not self-transferable. Furthermore, in all isolates belonging to sequence type ST-1, blacTX-M-15 was found integrated into the $K$. pneumoniae chromosome. In all the studied isolates, the mobile element ISEcp1 was found upstream

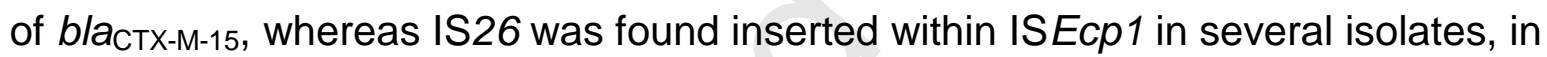
previously unreported positions. In conclusion, these findings indicate that among $K$. pneumoniae strains isolated in the Barcelona metropolitan area, bla with diverse genetic elements, including the IncR and IncFllk replicons, as reported for the first time here, and the chromosome. 


\section{Introduction}

The spread of antimicrobial-resistant pathogens is a serious clinical and public health problem worldwide. Recombination processes, including homologous recombination and transposition, constitute the major pathways for the capture and expression of resistance genes within mobile genetic elements that thereby intensively contribute to their dissemination. Regarding the high prevalence of bla CTX-M-15 $_{15}$ in Enterobacteriaceae, several reports have emphasised the importance of the insertion sequences ISEcp1 and IS26 in its mobilisation from the Kluyvera chromosome [1,2]. Furthermore, the rapid and international spread of bla $a_{\mathrm{CTX}-\mathrm{M}-15}$ has been mainly associated with the global dissemination of Escherichia coli clonal strains (i.e. sequence types ST-131 and ST-405)

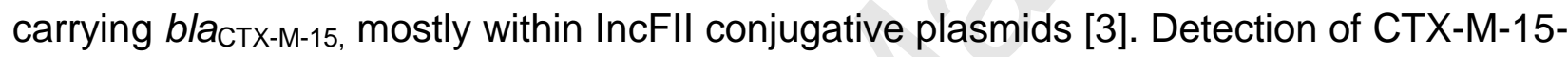
producing Klebsiella pneumoniae is also increasingly documented worldwide and some authors have proposed horizontal transmission of bla pneumoniae strains by conjugal transfer of IncFIl plasmids [4].

In a recent study [5] investigating the presence of CTX-M-15-producing K. pneumoniae clonal strains in the Barcelona metropolitan area from 2005 to 2008, we screened for bla $a_{\mathrm{CTX}-\mathrm{M}-15}$ among 111 non-duplicate extended-spectrum $\beta$-lactamase (ESBL)-producing $K$. pneumoniae isolates. We reported 37 CTX-M-15-producing K. pneumoniae isolates that, based on pulsed-field gel electrophoresis (PFGE), were classified in eight clonal clusters, corresponding with seven sequence types, as determined by multilocus sequence typing (MLST) [5]. Pulsotypes VII and VIII, which exhibited 79\% similarity, belonged to the same sequence type, i.e. ST-1 [5]. In the present report, we describe the location and genetic organisation of bla 


\section{Materials and methods}

\subsection{Bacterial isolates}

The 37 studied K. pneumoniae isolates represented all of the CTX-M-15-producing isolates found among 111 ESBL-producing $K$. pneumoniae collected from three hospitals within metropolitan Barcelona between 2005 and 2008, as previously reported [5]. According to 7-gene MLST, these isolates belonged to sequence types ST-1 $(n=12)$, ST$14(n=1)$, ST-37 $(n=1)$, ST-147 $(n=1)$, ST-321 $(n=1)$, ST-326 $(n=16)$ and ST-327 $(n=$ 5) $[5]$.

\subsection{Characterisation of the genetic environment of bla}

The genetic environment surrounding bla isolates by polymerase chain reaction (PCR) mapping and direct sequencing of both strands of the amplicons. To detect nucleotide sequences previously reported to be associated with blacTX-M-15, specific primers for the insertion sequences IS26 and ISEcp 1 (located upstream of bla downstream) were used in combination with bla

\subsection{Determination of plasmid replicon type}

Plasmid replicons were identified using the PCR-based replicon typing method as described previously [6], including screening for the $\mathrm{IncR}$ replicon that has been recently documented in Salmonella strains [7]. In addition, the repA gene associated with the replicon from the pKPN4 plasmid was amplified using primers RepFIlk-F (5'GGTTAAAAACCCGAATCCGG-3') and RepFIIk-R (5'-CAGTCGCGTGTAGTTGTTCC-3'). All positive results were confirmed by sequencing both strands of the amplicons. 


\subsection{Identification and characterisation of the location of bla $\mathrm{C}_{C \mathrm{X}-\mathrm{M}-15}$}

Plasmid number and sizing was performed on all $K$. pneumoniae isolates as well as all associated transconjugants or transformants by PFGE of total DNA digested with S1nuclease as previously described [8]. Restriction fragments from PFGE gels were then transferred onto positively charged nylon membranes and hybridised with specific probes for blacTX-M-15, aac(6')-Ib-cr and each previously identified replicon (i.e. FII, FIlk, R, N and L/M). A chromosomal location of blacTX-M-15 in the $K$. pneumoniae isolates was also screened for by the same method using PFGE and Southern hybridisations following ICeul nuclease digestion as previously described [9]. Specific probes for the 16S rRNA gene, blasHV-1 and seven housekeeping genes (infB, gapA, rpoB, $m d h$, phoE, tonB and pgi) were used for chromosomal detection [10].

\subsection{Plasmid mobilisation}

Based on the S1-nuclease experiment results, several representative isolates from each clonal cluster were selected for conjugation assays. Conjugation was carried out at $37^{\circ} \mathrm{C}$ and $30{ }^{\circ} \mathrm{C}$ using a rifampicin-resistant derivative of E. coli HB101 as recipient, selecting on Luria-Bertani (LB) agar plates supplemented with $100 \mu \mathrm{g} / \mathrm{mL}$ rifampicin and $10 \mu \mathrm{g} / \mathrm{mL}$ cefotaxime. For strains for which no transconjugant could be obtained, plasmids were extracted by the hot alkaline method [11] and were transformed by electroporation into $E$. coli HB101. Transformants were selected on LB agar plates containing $10 \mu \mathrm{g} / \mathrm{mL}$ cefotaxime. 


\section{Results and discussion}

\subsection{Genetic environment of bla CTX-M-15}

Four distinct genetic environments surrounding bla isolates. In isolates belonging to ST-1, ST-326, ST-37 and ST-321, an entire insertion sequence ISEcp1 was found 48 bp upstream of bla reports [2]. In isolates belonging to ST-327, ST-14 and ST-147, IS26 was found inserted at, respectively, 209, 497 and 594 nucleotides from the ISEcp1 terminus (submitted under GenBank accession nos. GQ845084, GQ845085 and GQ845086, respectively). Although the presence of IS26 in the genetic environment surrounding bla the particular insertion positions observed here have not been previously described, suggesting a different origin or a new reorganisation from those already described. In all isolates studied, open reading frame orf477 was detected downstream of blacTX-M-15, as previously described $[1,12]$.

\subsection{Localisation of bla}

PCR-based replicon typing and sequencing showed that replicons IncR, IncFIIA and IncN were present in ST-1 isolates. IncR is a replicon that was recently documented in a qnrS1carrying plasmid from Salmonella enterica isolates and corresponds to a replicon of the $K$. pneumoniae plasmid pK245, itself described as deriving from the $\beta$-replicon of the $K$. pneumoniae plasmid pGSH500 (96\% similarity between the protein sequences of the replicases from pK245 and pGSH500) [7,13]. In this study, sequences of the IncR PCR products obtained from the present Klebsiella isolates showed $100 \%$ identity with the replicase from pK245. Moreover, sequences of the IncFIIA PCR products obtained from ST-1 isolates correspond to replicase RepA from the replicon IncFIlk, as previously 
identified in K. pneumoniae plasmid pKPN4 (based on GenBank sequence NC_009650) (Table 1) [14].

Specific probe hybridisations of S1-digested DNA from ST-1 isolates demonstrated that isolates kp-57, kp-62 and kp-64 carried blacTX-M-15 and aac(6')-lb-cr on plasmids that exhibited replicon IncR (pST1-2,3) (Table 1; Fig. 1). The IncFllk replicon was identified by the same method in ST-1 isolate 19sp on a 190-kb bla (Table 1; Fig. 1). No IncN plasmid was found in association with blactX-M-15 (Table 1).

The remaining eight ST-1 isolates did not exhibit any plasmid carrying bla However, following restriction of their total DNA with the I-Ceul nuclease (i.e. chromosomal restriction), all ST-1 isolates, including the four carrying a plasmidic bla hybridised with the blacTX-M-15 probe on a very large (>2000 kb) I-Ceul-digested fragment. Although this fragment yielded only weak hybridisation with the 16S rRNA probe, it hybridised strongly with the gapA (Fig. 2) and blasHV-1 probes (data not shown), thereby definitively confirming the chromosomal localisation of blacTX-M-15 in these isolates. Although bla $\mathrm{SHV}_{\mathrm{1}}$ can be found not only in a chromosomal location but also in plasmids, this gene was used for the hybridisation experiment because within the chromosome of $K$. pneumoniae (based on GenBank sequence NC_009648), gapA and blasHV-1 are separated by only $437 \mathrm{~kb}$.

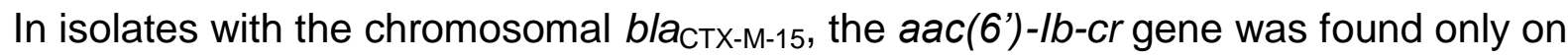
plasmids of molecular weight from $35 \mathrm{~kb}$ to $60 \mathrm{~kb}$ (paST1-1,2,3) (Table 1). These plasmids did not correspond with any of the incompatibility groups tested by replicon typing. 
Regarding the remaining $25 \mathrm{~K}$. pneumoniae isolates, PCR-based replicon typing and sequencing as well as Southern analysis of S1-digested DNA demonstrated that all 16 ST326 isolates carried bla $a_{\mathrm{CTX}-\mathrm{M}-15}$ plus aac(6')-Ib and/or aac(6')-Ib-cr (since these isolates carried both wild-type and bifunctional acetyltransferase-encoding genes [5]), co-localised on IncR plasmids of ca. 75, 85 and $90 \mathrm{~kb}$ (pST326-1,2,3) (Table 1). All five ST-327 isolates carried blacTX-M-15 on IncFII plasmids, which were of ca. $60 \mathrm{~kb}$ in four isolates (pST327-1) (Table 1; Fig. 1) and $30 \mathrm{~kb}$ in the fifth isolate (pST327-2) (Table 1). In the ST-37, ST-147, and ST-321 isolates, both blacTX-M-15 and aac(6')-Ib-cr were found on IncFII plasmids that ranged in size from $75 \mathrm{~kb}$ to $80 \mathrm{~kb}$ (pST37-1, pST147 and pST321) (Table 1; Fig. 1). Moreover, ST-37 isolate $23.1 \mathrm{sp}$ carried a second copy of these genes on a $290-\mathrm{kb}$ plasmid that was positive for both the FII and Fllk replicons (pST37-2) (Table 1). Notably, this isolate contained a third plasmid of ca. $190 \mathrm{~kb}$ that was positive for the IncFllk replicon (not shown in Table 1). These results are seemingly incompatible since in principle two plasmids belonging to the same Inc group cannot occur in the same host cell. Therefore, it is probable that another unknown replicon is present and expressed in at least one of these plasmids. Finally, isolate kp-71, representing ST-14, carried bla $a_{\mathrm{CTX}-\mathrm{M}-15}$ and aac(6')Ib and/or aac(6')-Ib-cr [5] on a 340-kb plasmid that was negative for all the incompatibility groups tested (pST14) (Table 1; Fig. 1).

Of note, neither IncR plasmids, previously reported in S. enterica and K. pneumoniae, or IncFIlk plasmids, previously reported only in K. pneumoniae, have been described in association with bla $a_{\mathrm{CTX}-\mathrm{M}-15}$. Moreover, none of the $K$. pneumoniae isolates not belonging to ST-1 exhibited a chromosomal copy of blactX-M-15 (Table 1). 
In this study, the IncR and IncFIlk replicons occurred in the majority of isolates (i.e. IncR in 33 isolates and IncFIlk in 26 isolates) (Table 1), with or without being associated with bla only a few isolates $(n=8)$, always associated with bla CTX-M-15. Although additional studies are needed to confirm these relationships, the present data would suggest that IncR and IncFIlk plasmids may benefit from good stability in K. pneumoniae, whereas IncFII plasmids perhaps are maintained in this host by means of selective advantage provided by blactX-M-15. This is consistent with the observation that IncFIlk and IncR plasmids appear to be associated with strains with a high capacity to diffuse and to persist in time, whereas IncFII plasmids were found in strains that have disseminated less extensively [5]. Notably, the genetic environment of bla entire ISEcp1 upstream of the gene, which may facilitate gene mobilisation, whereas in some IncFII plasmids the IS26 insertion within the tnpA of ISEcp1 may inhibit ISEcp1mediated mobilisation, trapping the gene in the plasmid, as previously described [15].

\subsection{Transferability of bla $a_{C T X-M-15}$}

To determine whether plasmids carrying bla $\mathrm{CTX-M-15}_{15}$ were self-transferable, conjugation experiments were performed with several isolates (Table 1). Transconjugants were obtained from isolates kp-57 (ST-1), 19sp (ST-1), kp-8 (ST-326), kp-71 (ST-14), 23.1sp (ST-37), kp-28 (ST-147) and 25sp (ST-321). In contrast, bla could not be similarly self-transferred from isolates kp-62 (ST-1), kp-64 (ST-1), 8H (ST326), kp-36 (ST-327) and kp-73 (ST-327). However, they could be mobilised by transformation. Isolate kp-30 (ST-1), for which only a chromosomal location of bla was detected, yielded neither transconjugants nor transformants, as expected. 
In transconjugants obtained from isolates $\mathrm{kp}-57,19 \mathrm{sp}, \mathrm{kp}-71,23.1 \mathrm{sp}$ and $25 \mathrm{sp}$, the plasmids carrying bla $a_{\mathrm{CTX}-\mathrm{M}-15}$ were of the same size and carried the same replicon as the plasmids from the donor strains. However, in the remaining two transconjugants (i.e. $\mathrm{TC}_{\mathrm{kp}-8}$ and $\left.\mathrm{TC}_{\mathrm{kp}-28}\right)$, the plasmids carrying bla $\mathrm{CTTX}-\mathrm{M}-15$ were larger than the corresponding donor strain's blactX-M-15-containing plasmids (Table 1; Fig. 1).

In the case of $\mathrm{TC}_{\mathrm{kp}-8}$, a $330-\mathrm{kb}$ plasmid was detected that was positive for blacTX-M-15 and for both replicons IncR and IncFIlk, whereas in donor strain kp-8 (from ST-326), the blactxM-15-carrying plasmid had a size of $90 \mathrm{~kb}$ and was positive only for IncR. Interestingly, the donor strain carried an additional plasmid of $205 \mathrm{~kb}$, positive for IncFllk (data not shown). Therefore, we hypothesise that the plasmid detected in the transconjugant was the result of a co-integration event involving both parental plasmids, which carried IncR (90 kb) and IncFIlk (205 kb), respectively.

Furthermore, the deduced Fllk replicon amino acid sequences obtained for all ST-326 isolates (including kp-8), using primers RepFllk, exhibited 97.6\% identity (six amino acid changes) with the reference RepA sequence from pKPN4 as well as $97.6 \%$ identity with the replicase associated with the $\alpha$-replicon carried by plasmid pGSH500, which in addition carried the first-described IncR replicon (based on GenBank sequence AJ009980.1) [15]. This Fllk variant sequence, designated Fllk- $\alpha$, was also obtained from the $\mathrm{TC}_{\mathrm{kp}-8} E$. coli, a result that may confirm the hypothesised co-integration event. Transformation experiments involving kp-8 yielded a transformant carrying only the $90-\mathrm{kb}$ IncR plasmid $\left(\mathrm{TF}_{\mathrm{kp}-8}\right)($ Table 1; Fig. 1). 
Regarding $\mathrm{TC}_{\mathrm{kp}-28}$, a similar recombination event may have occurred involving the IncFII blacTX-M-15-carrying plasmid (80 kb) and an IncN plasmid (30 kb) also present in the donor strain kp-28 (from ST-147) (not shown). In contrast, with isolate 23.1sp (from ST-37), although two bla $\mathrm{CTX}_{\mathrm{X}-\mathrm{M}-15}$-carrying plasmids were detected in the donor strain, in all the conjugation assays only the smaller of these, i.e. the $80-\mathrm{kb}$ IncFIl plasmid, was transferred to the recipient (Table 1; Fig. 1).

\section{Conclusion}

The present findings elucidate a series of genetic elements that likely contribute to the acquisition and maintenance of bla $\mathrm{C}_{\mathrm{CTX}-\mathrm{M}-15}$ in $\mathrm{K}$. pneumoniae, a species of particular clinical significance because of its current association with major hospital outbreaks. In particular, we provide evidence of blacTX-M-15 chromosomal integration in K. pneumoniae and document the first reported association of blacTX-M-15 with the two recently described replicons IncR and IncFllk. These findings reflect differences in the genetic vectors involved in the carriage of bla $a_{\mathrm{CTX}-\mathrm{M}-15}$ in $K$. pneumoniae versus those described in E. coli. These differences may contribute to the diffusion of bla Future epidemiological surveillance for bla $a_{\mathrm{CTX}-\mathrm{M}-15}$ in $K$. pneumoniae should be carried out to test this hypothesis.

\section{Funding}

This work was supported by Fondo de Investigación Sanitaria (PI050289), Ministerio de Sanidad y Consumo, Instituto de Salud Carlos III - FEDER (Spanish Network for Research in Infectious Diseases) (REIPIRD06/0008) and the Office of Research and

Development, Medical Research Service, Department of Veterans Affairs (JRJ). 
Competing interests

None declared.

\section{Ethical approval}

Not required. 


\section{References}

[1] Abbassi MS, Torres C, Achour W, Vinué L, Sáenz Y, Costa D, et al. Genetic characterisation of CTX-M-15-producing Klebsiella pneumoniae and Escherichia coli strains isolated from stem cell transplant patients in Tunisia. Int J Antimicrob Agents 2008;32:308-14.

[2] Lartigue MF, Poirel L, Nordmann P. Diversity of genetic environment of blacTX-M genes. FEMS Microbiol Lett 2004;234:201-7.

[3] Nicolas-Chanoine MH, Blanco J, Leflon-Guibout V, Demarty R, Alonso MP, Caniça MM, et al. Intercontinental emergence of Escherichia coli clone O25:H4-ST131 producing CTX-M-15. J Antimicrob Chemother 2008;61:273-81.

[4] Diestra K, Juan C, Curiao T, Moyá B, Miró E, Oteo J, et al. Characterization of plasmids encoding bla $a_{\mathrm{ESB}}$ and surrounding genes in Spanish clinical isolates of Escherichia coli and Klebsiella pneumoniae. J Antimicrob Chemother 2009;63:60-6.

[5] Coelho A, Mirelis B, Alonso-Tarrés C, Larrosa MN, Miró E, Abad RC, et al. Detection of three stable genetic clones of CTX-M-15-producing Klebsiella pneumoniae in the Barcelona metropolitan area, Spain. J Antimicrob Chemother 2009;64:862-4.

[6] Carattoli A, Bertini A, Villa L, Falbo V, Hopkins KL, Threlfall EJ. Identification of plasmids by PCR-based replicon typing. J Microbiol Methods 2005;63:219-28.

[7] García-Fernandez A, Fortini D, Veldman K, Mevius D, Carattoli A. Characterization of plasmids harbouring qnrS1, qnrB2 and qnrB19 genes in Salmonella. J Antimicrob Chemother 2009;63:274-81.

[8] García A, Navarro F, Miró E, Villa L, Mirelis B, Coll P, et al. Acquisition and diffusion of

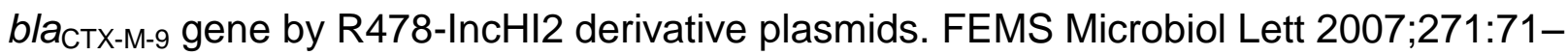
7. 
[9] Liu SL, Hessel A, Sanderson KE. Genomic mapping with I-Ceu I, an intron-encoded endonuclease specific for genes for ribosomal RNA, in Salmonella spp., Escherichia coli, and other bacteria. Proc Natl Acad Sci USA 1993;90:6874-8.

[10] Diancourt L, Passet V, Verhoef J, Grimont PA, Brisse S. Multilocus sequence typing of Klebsiella pneumoniae nosocomial isolates. J Clin Microbiol 2005;43:4178-82.

[11] Kado Cl, Liu ST. Rapid procedure for detection and isolation of large and small plasmids. J Bacteriol 1981;145:1365-73.

[12] Gonullu N, Aktas Z, Kayacan CB, Salcioglu M, Carattoli A, Yong DE, et al.

Dissemination of CTX-M-15 $\beta$-lactamase genes carried on Inc FI and FII plasmids among clinical isolates of Escherichia coli in a university hospital in Istanbul, Turkey. J Clin Microbiol 2008;46:1110-2.

[13] Chen YT, Shu HY, Li LH, Liao TL, Wu KM, Shiau YR, et al. Complete nucleotide sequence of pK245, a 98-kilobase plasmid conferring quinolone resistance and extended-spectrum- $\beta$-lactamase activity in a clinical Klebsiella pneumoniae isolate. Antimicrob Agents Chemother 2006;50:3861-6.

[14] Carattoli A. Resistance plasmid families in Enterobacteriaceae. Antimicrob Agents Chemother 2009;53:2227-38.

[15] Ensor VM, Jamal W, Rotimi VO, Evans JT, Hawkey PM. Predominance of CTX-M15 extended spectrum $\beta$-lactamases in diverse Escherichia coli and Klebsiella pneumoniae from hospital and community patients in Kuwait. Int $\mathrm{J}$ Antimicrob Agents 2009;33:487-9. 
Fig. 1. (a) Pulsed-field gel electrophoresis (PFGE) analysis of S1-digested DNA from transconjugants or transformants obtained from the studied CTX-M-15-producing Klebsiella pneumoniae isolates. (b) Southern hybridisation of S1-digested DNA with probe

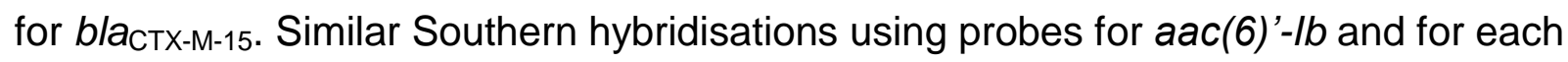
replicon were done with S1-digested fragments from all study K. pneumoniae. The corresponding results are detailed in Table 1. MK, phage $\lambda$ DNA marker.

Fig. 2. (a) Pulsed-field gel electrophoresis (PFGE) analysis of I-Ceul-digested genomic DNA from CTX-M-15-producing Klebsiella pneumoniae isolates representing sequence type ST-1 (kp-44 to kp-52), ST-327 (kp-66 and kp-36), ST-14 (kp-71) and ST-321 (25sp). (b-d) Southern hybridisation of I-Ceul-digested DNA with probes for blacTX-M-15 (b), $16 \mathrm{~S}$ rRNA (c) and gapA (d). Horizontal arrows to the left of blots indicate genomic bands hybridising with the bla $a_{\mathrm{CTX}-\mathrm{M}-15}$ probe. The down-pointing arrow in blot (b) corresponds to

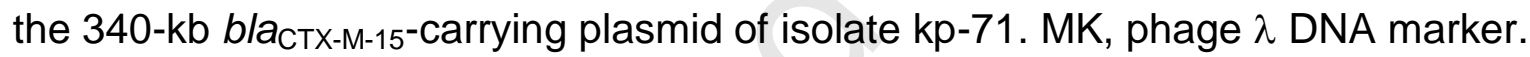




\section{Table 1}

Identification and characterisation of the location of bla

\begin{tabular}{|c|c|c|c|c|c|c|c|c|c|c|c|c|}
\hline \multirow[t]{3}{*}{ ST } & \multirow[t]{3}{*}{ Isolate } & \multirow[t]{3}{*}{ Year } & \multirow{3}{*}{$\begin{array}{l}\text { Replicons } \\
\text { detected }^{a}\end{array}$} & \multicolumn{6}{|c|}{ bla $a_{\mathrm{CTX}-\mathrm{M}-15}$} & \multicolumn{3}{|l|}{$a a c-6$ '-lb } \\
\hline & & & & \multicolumn{6}{|c|}{ Location } & \multirow{2}{*}{$\begin{array}{l}\text { Location } \\
\text { c }\end{array}$} & \multirow[t]{2}{*}{$\operatorname{lnc}{ }^{d}$} & \multirow{2}{*}{$\begin{array}{l}\text { Plasmid } \\
\text { size }(k b)\end{array}$} \\
\hline & & & & $\mathrm{cr}^{\mathrm{b}}$ & $\begin{array}{l}\text { Plasmid } \\
\text { c }\end{array}$ & $\ln c^{d}$ & $\begin{array}{l}\text { Plasmid } \\
\text { size }(k b)\end{array}$ & $\begin{array}{l}\text { Recipient/plasmid } \\
\text { size (kb) }\end{array}$ & $\operatorname{lnc}^{d}$ & & & \\
\hline 1 & $\mathrm{kp}-57$ & 2007 & $\mathrm{R}$ & + & pST1-3 & $\mathrm{R}$ & 60 & $\mathrm{TC}_{\mathrm{kp}-57} / 60$ & $\mathrm{R}$ & pST1-3 & $\mathrm{R}$ & 60 \\
\hline 1 & kp-62 & 2007 & Fllk, R & + & pST1-2 & $\mathrm{R}$ & 55 & $\mathrm{TF}_{\mathrm{kp}-62} / 55$ & $\mathrm{R}$ & pST1-2 & $\mathrm{R}$ & 55 \\
\hline 1 & kp-64 & 2007 & Fllk, R & + & pST1-2 & $R$ & 55 & $\mathrm{TF}_{\mathrm{kp}-64} / 55$ & $\mathrm{R}$ & pST1-2 & $\mathrm{R}$ & 55 \\
\hline 1 & $19 s p$ & 2005 & Fllk & + & pST1-1 & Fllk & 190 & $\mathrm{TC}_{19 \mathrm{sp}} / 190$ & Fllk & neg. & - & - \\
\hline 1 & 11.1sp & 2005 & Fllk, R & + & neg. & - & - & $\mathrm{N} / \mathrm{D}$ & $\mathrm{N} / \mathrm{D}$ & paST1-1 & neg. & $<48$ \\
\hline 1 & $17 s p$ & 2005 & Fllk, R & + & neg. & - & - & $\mathrm{N} / \mathrm{D}$ & $\mathrm{N} / \mathrm{D}$ & paST1-1 & neg. & $<48$ \\
\hline 1 & $21 s p$ & 2005 & Fllk, R & + & neg. & - & - & $\mathrm{N} / \mathrm{D}$ & $N / D$ & $\begin{array}{l}\text { paST1- } \\
1,2\end{array}$ & neg. & $\begin{array}{l}48 \text { and } \\
35\end{array}$ \\
\hline 1 & kp-30 & 2007 & Fllk, R & + & neg. & - & - & neg. & - & paST1-3 & neg. & 60 \\
\hline 1 & $\mathrm{kp}-44$ & 2007 & Fllk, R, N & + & neg. & - & - & $\mathrm{N} / \mathrm{D}$ & N/D & neg. & - & - \\
\hline 1 & $15 s p$ & 2005 & Fllk, R & + & neg. & - & - & $N / D$ & $N / D$ & paST1-1 & neg. & 48 \\
\hline 1 & kp-34 & 2007 & $\mathrm{R}$ & + & neg. & - & - & $\mathrm{N} / \mathrm{D}$ & $N / D$ & paST1-1 & neg. & 48 \\
\hline 1 & kp-52 & 2007 & $\mathrm{R}$ & + & neg. & - & - & $\mathrm{N} / \mathrm{D}$ & $N / D$ & neg. & - & - \\
\hline 326 & $\begin{array}{l}1 \mathrm{H}- \\
13 \mathrm{H}^{\mathrm{e}}\end{array}$ & 2008 & Fllk- $\alpha^{f}, R$ & neg. & $\begin{array}{l}\text { pST326- } \\
1\end{array}$ & $\mathrm{R}$ & 85 & $\mathrm{TF}_{8 \mathrm{H}} / 70$ & $\mathrm{R}$ & pST326 & $\mathrm{R}$ & 85 \\
\hline
\end{tabular}




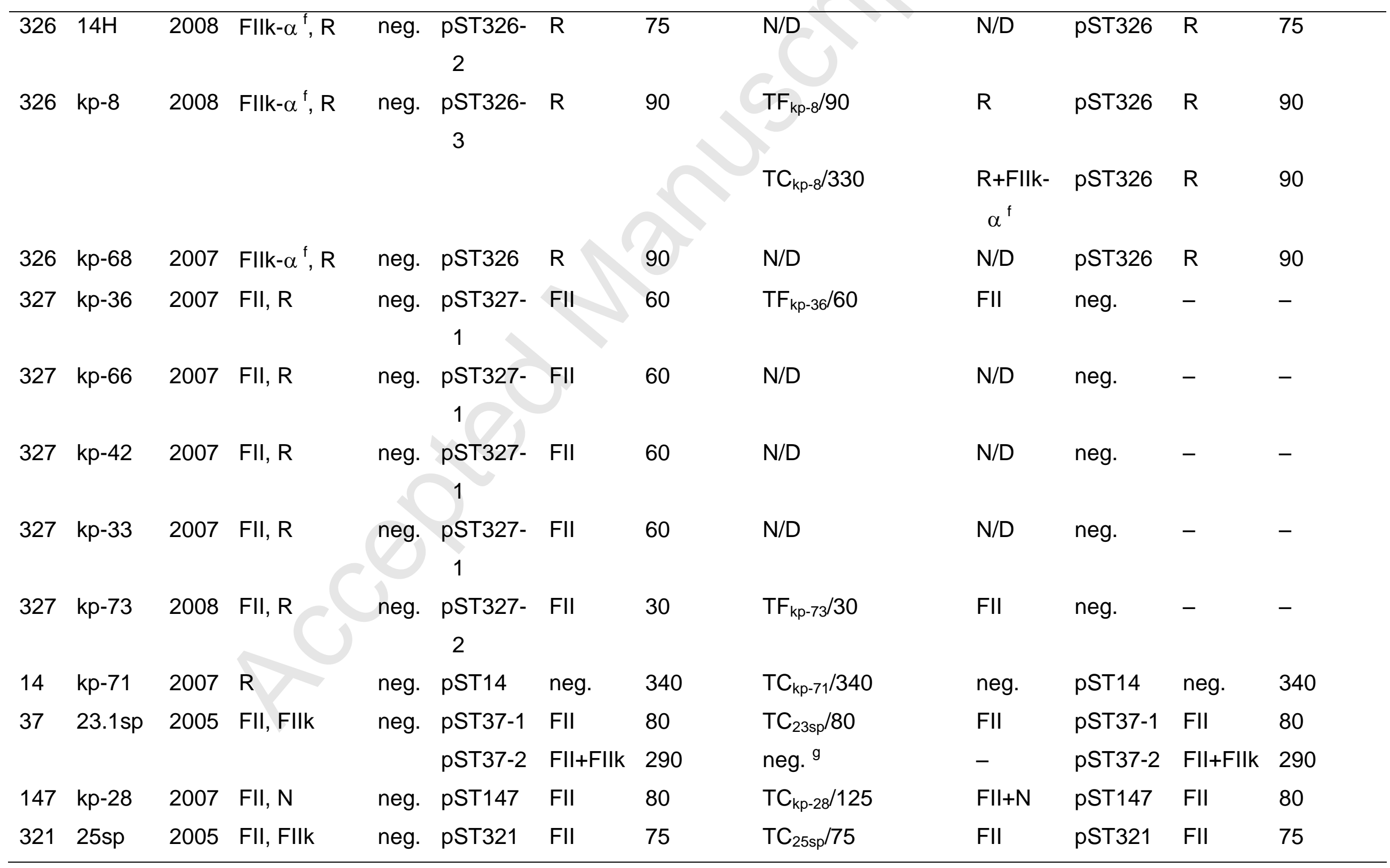


$\mathrm{p}$ (ST number), plasmid location; cr, chromosomal location, TF, transformant, TC, transconjugant; Inc, identified replicon; N/D, not done; neg., negative result; PCR, polymerase chain reaction.

${ }^{a}$ Replicon identifications are based on positive amplifications from the PCR-based replicon typing method and sequencing.

${ }^{\mathrm{b}}$ Results from the screening of bla $\mathrm{CTX- \textrm {M } - 1 5}$ chromosomal location: +, presence of blactX-M-15 within the chromosome; neg., absence of bla

${ }^{c}$ Plasmids were arbitrarily named based on the source strain sequence type and plasmid size.

${ }^{\mathrm{d}}$ In all K. pneumoniae isolates and all transconjugants or transformants, replicons from plasmids containing bla identified by PCR-positive amplification and by Southern hybridisation of the corresponding S1-digested fragments, as described in Section 2.3.

e This group included 13 isolates $(1 \mathrm{H}-13 \mathrm{H})$.

${ }^{\dagger}$ The deduced Fllk amino acid sequences obtained from all isolates belonging to ST-326 showed $97.6 \%$ similarity with RepA from pKPN4 and was referred to as Fllk- $\alpha$, as explained in the Section 3.3.

${ }^{9}$ Conjugation and transformation assays allowed isolation of the $80-\mathrm{kb}$ plasmid; the $290-\mathrm{kb}$ plasmid could not be isolated. 
(a)

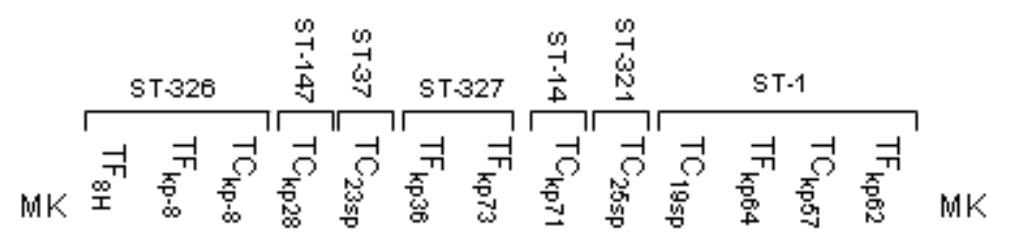

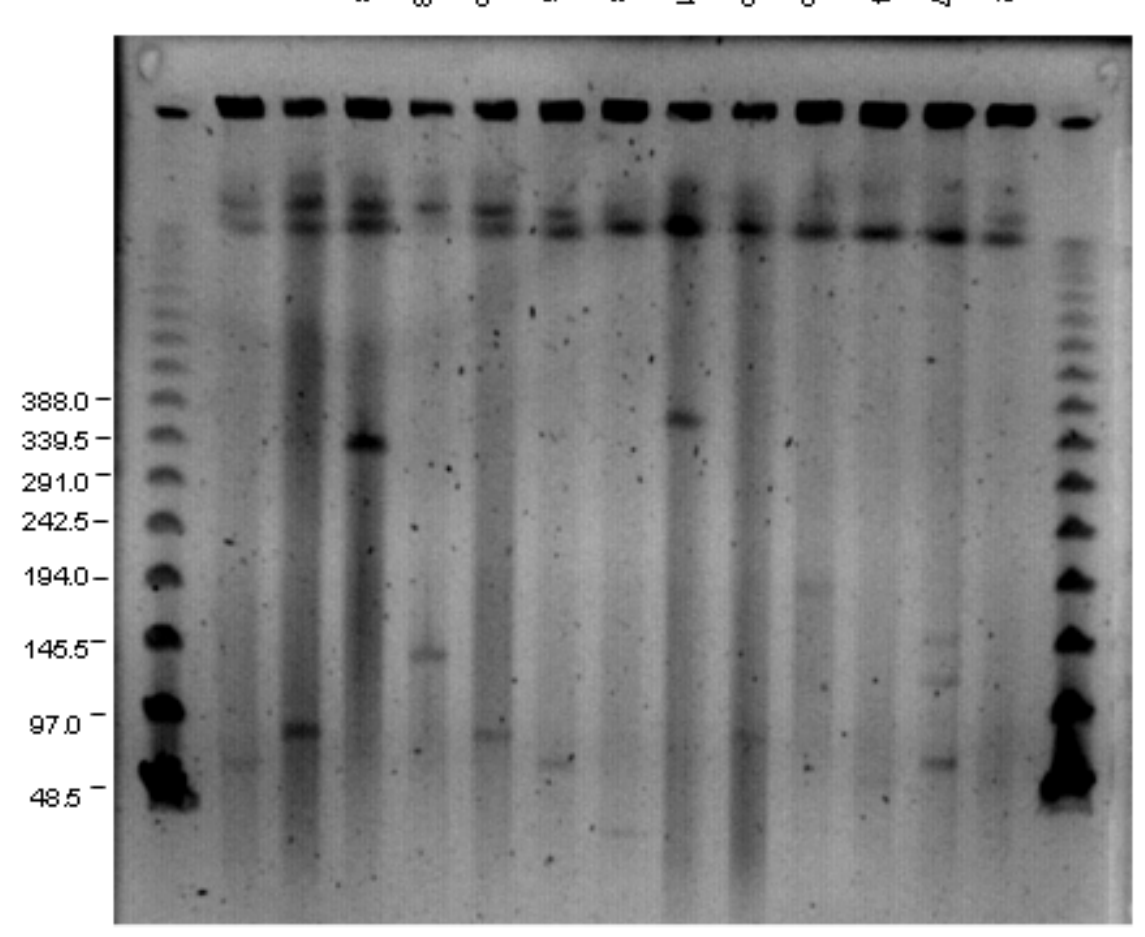

(b)
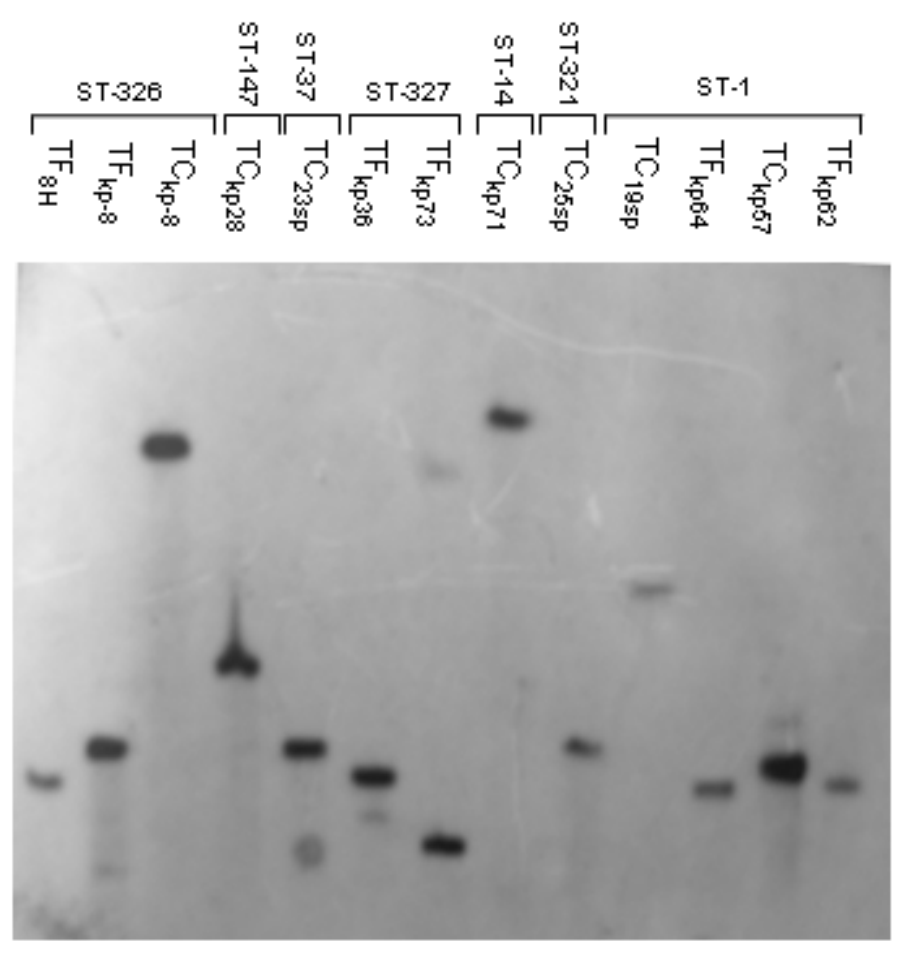

Figure 1: (a) PFGE analysis of S1-digested DNA from transconjugants or transformants obtained from the studied CTX-M-15-producing Klebsiella pneumoniae isolates. (b) Southern hybridization of S1-digested DNA with probe for $\underline{b l a}_{\mathrm{CTX}-\mathrm{M}-15}$. Similar Southern hybridizations using probes for $a a c(6)$ '-Ib, and for each replicon, were done with $S 1$-digested fragments from all study K. pneumoniae. The corresponding results are detailed in Table 1. 

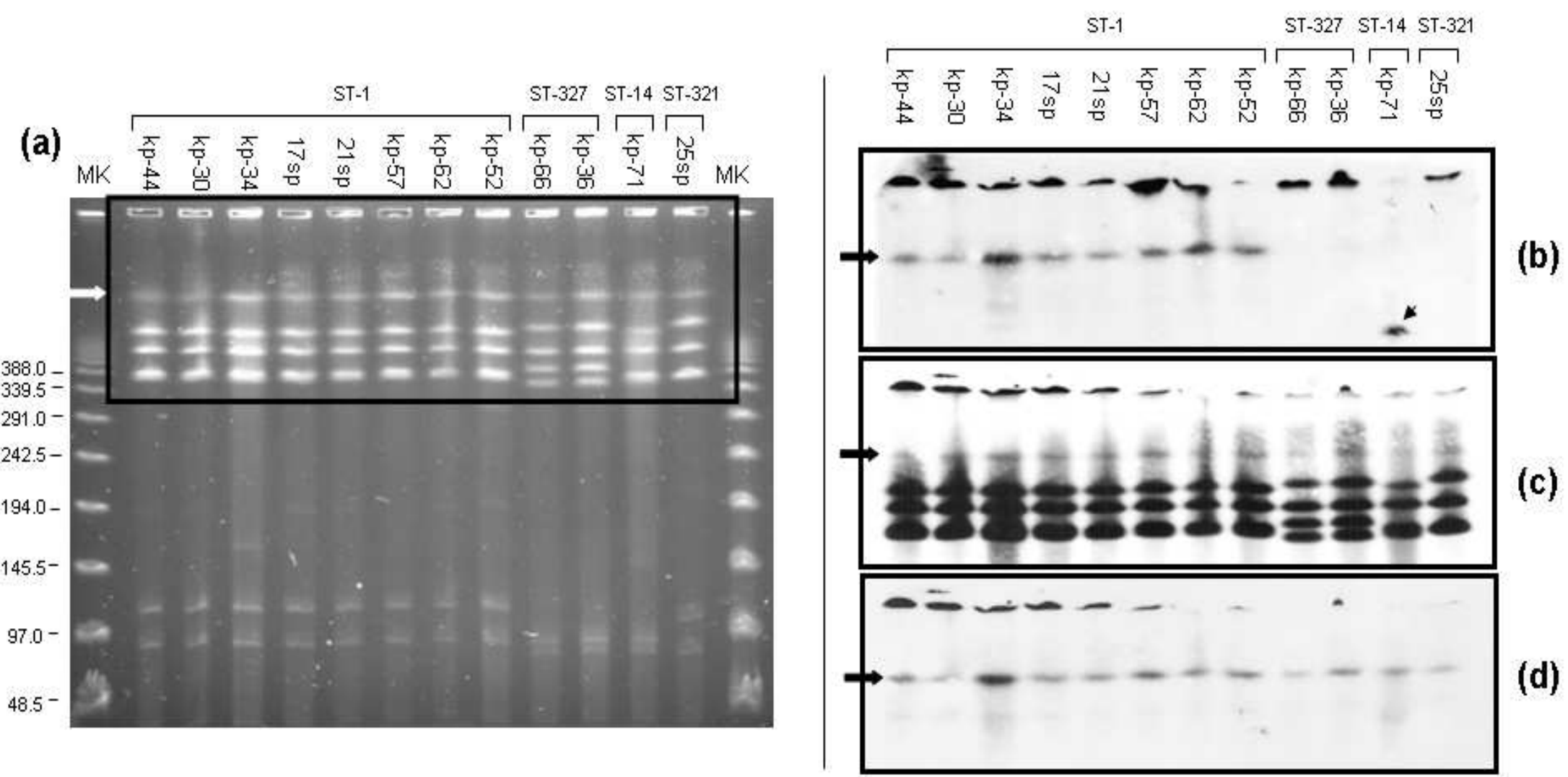

Figure 2: (a) PFGE analysis of I-CeuI-digested genomic DNA from CTX-M-15-producing Klebsiella pneumoniae isolates representing ST-1 (kp-44 to kp-52), ST-327 (kp-66 and kp-36), ST-14 (kp-71), and ST-321 (25sp). (b-d) Southern hybridization of I-CeuI-digested DNA with probes for (b) $\underline{b l a}_{\mathrm{CTX}-\mathrm{M}-15}$, (c) $16 \mathrm{~S}$ rRNA, and (d) gapA. Horizontal arrows at left of blots indicate genomic bands hybridizing with the $\underline{b l a}$ CTX-M-15

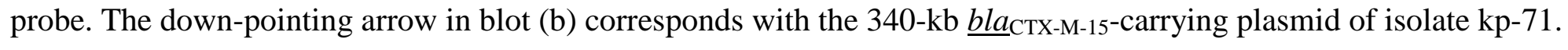

Abbreviations: MK, phage $\lambda$ DNA marker. 